\title{
FIRST RECORD OF A WESTERN MASCARENE ENDEMIC, HALICHOERES PELICIERI (ACTINOPTERYGII: PERCIFORMES: LABRIDAE), FROM REUNION ISLAND
}

\author{
Julien WICKEL ${ }^{1 *}$, Mathieu PINAULT ${ }^{1,2}$, and Ronald FRICKE ${ }^{3,4}$ \\ ${ }^{1}$ MAREX Ltd-Marine expertise Company, Les Avirons, Reunion Island \\ ${ }^{2}$ UMR 9220 ENTROPIE, UR CNRS IRD, University of Reunion, France \\ ${ }^{3}$ Im Ramstal 76, 97922 Lauda-Königshofen, Germany \\ ${ }^{4}$ Staatliches Museum für Naturkunde, Stuttgart, Germany
}

Wickel J., Pinault M., Fricke R. 2016. First record of a western Mascarene endemic, Halichoeres pelicieri (Actinopterygii: Perciformes: Labridae), from Reunion Island. Acta Ichthyol. Piscat. 46 (1): 33-35.

\begin{abstract}
Known to date as endemic to Mauritius Island (Mascarene Islands, Indian Ocean), Halichoeres pelicieri Randall et Smith, 1982 is recorded herewith for the first time from Reunion Island shore. This new observation expands the range of $H$. pelicieri to the western Mascarene Islands and strengthens the dispersal connection hypothesis from Mauritius to Reunion. It also emphasizes the importance to improve the prospecting effort on non-reef habitats in order to access to a better understanding of biodiversity and ecological functionalities of these often little studied habitats.
\end{abstract}

Keywords: new record, south-western Indian Ocean, geographic distribution, connectivity, associated coral reef ecosystems

Although the study of ichthyological diversity from Reunion island dates back to the late 18th century and resulted in identification of 984 fish species representing 164 families (Fricke et al. 2009), new records are still quite common. The exploration of non-reef habitats, some of which remain poorly studied at the island scale, leads frequently to the observation of previously unrecorded species (Pinault et al. 2013, Pinault et al. 2014, Pinault et al. 2015). This paper reports a sighting of a species that had not previously been recorded from Reunion, recorded during an environmental survey on the northeast coast of the island. During the survey, a group of wrasses characterized by a broad yellow lateral stripe, was observed and photographed. The subsequent analysis of their morphological characters revealed that we dealt with specimens of the Pelicier's wrasse, Halichoeres pelicieri Randall et Smith, 1982, known to date as endemic to Mauritius Island. This study provides a morphological characterization of a single observed individual, based on the photographic evidence. The reported finding extends the range of distribution of the species.

Individuals of Halichoeres pelicieri, described in this study have been observed during an environmental survey carried out as an underwater visual census on 18 November 2014 at 1100 hours. The observation took place on the northeast shore of Reunion Island at Bois Rouge site $\left(20^{\circ} 54^{\prime} \mathrm{S} ; 55^{\circ} 38^{\prime} \mathrm{E}\right)$, at the depth of $22 \mathrm{~m}$ and water temperature of $26^{\circ} \mathrm{C}$ (Fig. 1).

The fish observed have been identified following Randall and Smith (1982). The visual overestimate of the fish total length (TL), due to the modification of the vision

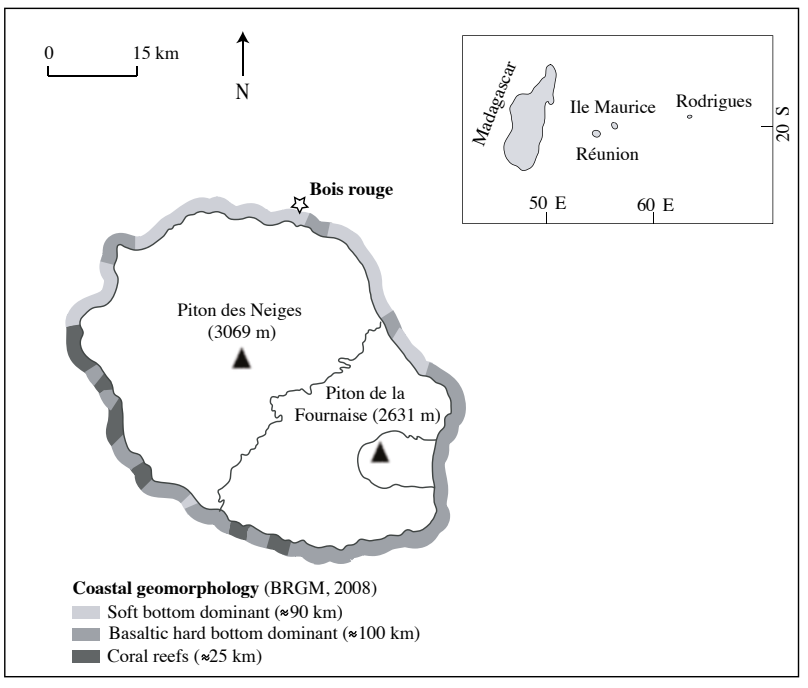

Fig. 1. Coastal geomorphology of Reunion Island and location of the station (star) of the specimens of Halichoeres pelicieri described and illustrated in this study 
in scuba diving (increasing of the object lengths), was adjusted according to Edgar et al. (2004). Proportional body measurements were recorded ex post, on photographic basis, to calculate standard length (SL), head length (HL), body depth (BD), and orbit diameter (OD), and were presented as percentages of the SL following Randall and Smith (1982).

One photographed female had an estimated TL of 7.0 $\mathrm{cm}$, SL of $5.8 \mathrm{~cm}$, HL of $1.7 \mathrm{~cm}$, BD of $1,6 \mathrm{~cm}$, and OD of $0.3 \mathrm{~cm}$. The proportions calculated from the estimated size were: HL ca. $29 \%$, BD ca. $28 \%$, and OD ca. $5 \%$ of SL. The individual studied was characterized by having a broad yellow stripe extending from tip of snout through eye to caudal fin just above mid-length of body, ending in a large black spot slightly above mid-base of caudal fin (Fig. 2). The rest of body mainly blue with pinkish mottlings. Dorsal fin translucent with a broadly pale yellow margin slightly rounded caudal fin translucent with a tinge of yellow.

The photographed individual was part of a loose group of six individuals, including one male and a harem of females. The observed male colour pattern was pink bands on the head, thorax, and abdomen, and no large black spot on or below the lateral line.

Individuals were swimming close to the sea bottom, independently but in a cohesive social group without synchronous swimming, which characterizes shoaling species (Pitcher 1998). Individuals were feeding on small invertebrates living on the bottom. The benthic habitat of the observed area was characterized by decimetricsize boulders scattered on a sandy bottom sloping gently into the deep water at an angle of ca. $5^{\circ}$, with a high hard substrate covered by algae, encrusting sponges and hydroids. The sedimentation rate seemed to be high as shown by the thick silt film covering boulders.

Remarks. The Pelicier's wrasse, Halichoeres pelicieri, was originally described and figured by Randall and Smith (1982) on the basis of six specimens from Mauritius. Since then, two alleged sightings, one from South Africa and the other from Mozambique, were found to be errors based on misidentification (P.C. Heemstra, personal communication) and the species has been considered endemic to Mauritius (Parenti and Randall 2000, Kuiter 2002).

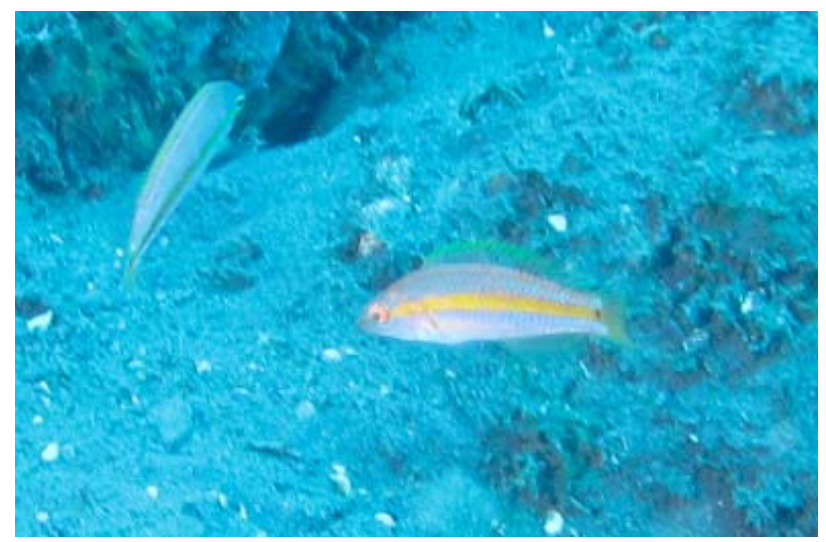

Fig. 2. Specimens of Halichoeres pelicieri photographed at Reunion Island on 18 November 2014 at the Bois rouge site (depth $22 \mathrm{~m}$ )
The individual photographed and presented in this study well matches the description of Halichoeres pelicieri given in Randall and Smith (1982) and the photographs of females provided by Kuiter (2002). However, it is very similar to the initial phase of Halichoeres zeylonicus (Bennett, 1833), both having a longitudinal yellow stripe and a black spot on the caudal peduncle. Nevertheless, the observed male colour pattern clearly allows an identification of the individuals as H. pelicieri. The habitat, where individuals from Reunion have been observed, was also comparable to the typical one described in Mauritius as open rubble and sand bottom, on the depth between 20 and $35 \mathrm{~m}$ (Randall and Smith 1982).

This new observation from Reunion Island expands the known range of Halichoeres pelicieri to the western Mascarene Islands. It also highlights the importance of the northeast shore of Reunion as a settlement site for post-larval settlers from Mauritius, and strengthens the dispersal connection hypothesis from Mauritius to Reunion (Crochelet et al. 2013).

More broadly, and as already shown by Wickel et al. (2014) in Mayotte Island, the relatively small number of studies on ecosystems associated with coral reefs (seagrass beds, estuaries, deep and rocky reefs, etc.) compared to the number of studies on coral reefs sensu stricto, identifies them as territories whose biodiversity is still largely underestimated. The opening of the scope of investigation into these peripheral areas probably will expand the number of species recorded in Reunion, but also in all coral reef islands of the South-western Indian Ocean

\section{REFERENCES}

Crochelet E., Chabanet P., Pothin K., Lagabrielle E., Roberts J., Pennober G., Lecompte-Finiger R., Petit M. 2013. Validation of a fish larvae dispersal model with otolith data in the western Indian Ocean and implications for marine spatial planning in datapoor regions. Ocean and Coastal Management 86: 13-21.

DOI: $10.1016 /$ j.ocecoaman.2013.10.002

Edgar G.J., Barrett N.S., Morton A.J. 2004. Biases associated with the use of underwater visual census techniques to quantify the density and size-structure of fish populations. Journal of Experimental Marine Biology and Ecology 308 (2): 269-290.

DOI: $10.1016 /$ j.jembe.2004.03.004

Fricke R., Mulochau T., Durville P., Chabanet P., Tessier E., Letourneur Y. 2009. Annotated checklist of the fish species (Pisces) of La Réunion, including a Red List of threatened and declining species. Stuttgarter Beiträge zur Naturkunde A, Neue Serie 2: $1-168$.

Kuiter R.H. 2002. Fairy and rainbow wrasses and their relatives. A comprehensive guide to selected labroids. TMC Publishing, Chorleywood, Herts, UK.

Parenti P., Randall J.E. 2000. An annotated checklist of the species of the labroid fish families Labridae and Scaridae. Ichthyological Bulletin 2000 (68): 1-97. 
Pinault M., Loiseau N., Chabanet P., Durville P., Pitcher T.J. 1998. Shoaling and schooling in fishes. Pp. Magalon H., Quod J.P., Galzin R. 2013. Marine fish communities in shallow volcanic habitats. Journal of Fish Biology 82 (6): 1821-1847.

DOI: $10.1111 / \mathrm{jfb} .12110$

Pinault M., Fricke R., Wickel J., Péneau C., Quod J.-P. 2015. First record of the chocolate shrimp-goby (Gobiidae: Cryptocentrus malindiensis) from Réunion Island with a brief description of its natural habitat. Cybium 39 (3): 237-239.

Pinault M., Wickel J., Guyomard D., Fricke R., Quod J.-P. 2014. Premier signalement de Pseudanthias bicolor (Serranidae) sur différents habitats artificiels à La Réunion. Cybium 38 (4): 255-259. 748-760. In: Greenberg G., Hararway M.M. (eds.) Comparative psychology: A handbook. Garland, New York, USA.

Randall J.E., Smith M.M. 1982. A review of the labrid fish genus Halichoeres of the western Indian Ocean, with descriptions of six new species. Ichthyological Bulletin of the J.L.B. Smith Institute of Ichthyology 45: 1-26.

Wickel J., Jamon A., Pinault M., Durville P., Chabanet P. 2014. Composition et structure des peuplements ichtyologiques marins de l'île de Mayotte (sud-ouest de l'océan Indien). Cybium 38 (3): 179-203.

Received: 17 November 2015

Accepted: 18 December 2015

Published electronically: 31 March 2016 